\title{
KEDUDUKAN SURAT KETETAPAN PEMBERHENTIAN PENUNTUTAN PERKARA (SKP3) (Mengkritisi SKP3 Kasus Mantan Presiden Soeharto)
}

\author{
Umi Supraptiningsih \\ (Jurusan Syari'ah STAIN Pamekasan, alumni S2 Universitas Narotama Surabaya, \\ dan peserta Program Doktor Ilmu Hukum Untag Surabaya)
}

\begin{abstract}
Abstrak
Kejaksaan sebagai pejabat fungsional dalam melaksanakan tugas dan wewenangnya, bertindak untuk dan atas nama negara serta bertanggung jawab menurut saluran hierarki. Untuk terciptanya penegakan hukum dan menjamin wibawa hukum di Indonesia diharapkan dalam mengambil keputusan berupa penetapan sebagaimana yang telah dikeluarkan berupa Surat Ketetapan Pemberhentian Penuntutan Perkara (SKP3) harus mendasarkan demi kepentingan bangsa dan negara serta ketertiban umum. Dengan mendasarkan pada ketentuan tersebut, maka kedudukan SKP3 tersebut masih dapat dilakukan praperadilan.
\end{abstract}

\section{Kata Kunci:}

SKP3, penuntut umum, hakim, dan kejaksaan

\section{Pendahuluan}

Dengan semakin memburuknya kondisi kesehatan mantan presiden RI kedua Soeharto (sakit permanen/kerusakan otak permanen) pada beberapa hari terakhir ini, kondisi yang demikian ternyata telah mendesak pemerintah untuk sesegera mungkin mengambil solusi hukum atas kasus dugaan korupsi Pak Harto. Setelah presiden Susilo Bambang Yudoyono mengajak bertemu beberapa pimpinan Lembaga Tinggi Negara pada tanggal 10 Mei 2006 yang berakhir pada pukul 00.15 WIB barulah pemerintah memutuskan untuk menghentikan proses hukum atas dugaan 


\section{Umi Supraptiningsih}

korupsi mantan presiden Soeharto dengan pertimbangan politik, hukum, kemanusiaan, kesehatan dan moral. ${ }^{1}$

Pada akhirnya terbitlah SKP3 (Surat Ketetapan Penghentian Penuntutan Perkara) pada tanggal 11 Mei 2006 yang diterbitkan oleh Kejaksaan Negeri Jakarta Selatan atas instruksi Jaksa Agung. Dengan dikeluarkannya SKP3 tersebut tentunya proses hukum atas Pak Harto menjadi mandeg.

Keluarnya SKP3 tersebut, ternyata membuat sebagian besar masyarakat Indonesia tidak bisa menerima dengan lapang dada (legowo), setiap hari diberbagai daerah terjadi demo baik yang dilakukan oleh mahasiswa, Lembaga Swadaya Masyarakat (LSM), maupun masyarakat pada umumnya yang menginginkan kasus dugaan korupsi Pak Harto harus tetap diproses secara hukum dan persoalan nantinya diberi pengampunan masih terbuka peluangnya setelah ada keputusan hakim yang berkekuatan hukum tetap (inkracht).

Yang menjadi pertanyaan bagi kita, dengan SKP3 tersebut bagaimana dengan kewibawaan hukum di Indonesia yang nota bene Indonesia adalah negara hukum², di mana penegakan hukum harus dijunjung tinggi.

\section{Kekuasaan Kehakiman Yang Merdeka (The Independence of the Judiciary)}

Pengertian Kekuasaan kehakiman mencakup arti kekuasaan kehakiman yang bebas, berwibawa dan bertanggung jawab menurut UUD 1945 yang bersumber pada dasar falsafah negara Pancasila. Kekuasaan kehakiman merupakan salah satu unsur pokok (soko guru) negara hukum yang bersumber pada cita hukum (rechts idee). ${ }^{3}$ Menurut ketentuan Pasal 24 ayat (1) dan (2) UUD 1945, menyebutkan :

(1) Kekuasaan kehakiman merupakan kekuasaan yang merdeka untuk menyelenggarakan peradilan guna menegakkan hukum dan keadilan (disahkan pada amandemen ketiga).

\footnotetext{
1 Jawa Pos, 11 Mei 2006.

2 Pasal 1 ayat (3) UUD 1945 hasil amandemen ketiga.

3 Rechts idee mengandung unsur-unsur filosofis : a. tata hukum (rechtsorde) yang penjabarannya dalam bentuk "wet" (=undang-undang); b. Rechts ada 2 arti yaitu : Rechts in Objectieve zin (=hukum) dan Rechts in subjectieve zin (=hak)
} 


\section{Kedudukan Surat Ketetapan Pemberhentian Penuntutan Perkara (SKP3)}

(2) Kekuasaan kehakiman dilakukan oleh sebuah Mahkamah Agung dan badan peradilan yang berada dibawahnya dalam lingkungan peradilan umum, lingkungan peradilan agama, lingkungan peradilan militer, lingkungan peradilan tata usaha negara, dan oleh sebuah Mahkamah Konstitusi (disahkan pada amandemen ketiga).

Begitu pula dipertegas dengan Pasal 1 UU Nomor 4 Tahun 2004 tentang Kekuasaan Kehakiman yang menyebutkan bahwa:

“Kekuasaan kehakiman adalah kekuasaan Negara yang merdeka untuk menyelenggarakan peradilan guna menegakkan hukum dan keadilan berdasarkan Pancasila demi terselenggaranya Negara Hukum Republik Indonesia".

Maksud dari kekuasaan kehakiman yang merdeka adalah kekuasaan kehakiman yang tidak boleh dicampuri oleh kekuasaan eksekutif dan legislatif dalam melaksanakan fungsi peradilan. Untuk itu perlu pengaturan undang-undang bagi pelaksanaan fungsi peradilan agar tidak dicampuri atau dimasuki pengaruh kekuasaan lain demi kepentingan/perlindungan hak-hak terdakwa atau pencari keadilan.

Memang sulit untuk menciptakan kekuasaan kehakiman dalam posisi "independen", kalaupun ada kekuasaan kehakiman yang independen berarti peradilan menjadi suatu mekanisme yang kuat untuk mempertahankan hukum/konstitusi dan keadilan. Dari uraian ini jelas ada korelasi antara fungsi yudikatif/peradilan dan proses demokrasi dimana pembentukan dan jaminan independensi atau kebebasan kekuasaan kehakiman seharusnya diciptakan secara aktif oleh semua sarjana hukum, polisi, kejaksaan dan penegak hukum lainnya. Independency kekuasaan kehakiman dapat diuji melalui dua cara, yaitu: (1) ketidakberpihakan (impartiality); (2) terputusnya hubungan atau relasi dengan elite politik (political insularity).

Impartialitas hakim terlihat pada gagasan bahwa para hakim akan mendasarkan putusannya pada hukum dan fakta-fakta di persidangan bukan atas dasar keterkaitan dengan salah satu pihak yang berperkara. Impartialitas hakim bukan sesuatu yang mudah dideteksi di mana hal itu bisa dilacak dari tingkah lakunya selama menjadi hakim dalam kaitannya dengan perkara tersebut. 


\section{Umi Supraptiningsih}

Impartialitas proses peradilan hanya dapat dilakukan jika hakim dapat melepaskan diri dari konflik kepentingan atau Collegialitas dengan pihak yang berperkara karena itu hakim harus mengundurkan diri dari proses persidangan jika ada potensi impartialitas. Dalam Sistem hukum Indonesia hakim harus mengundurkan diri jika memiliki hubungan darah atau semenda dengan salah satu pihak yang berperkara di pengadilan.

Pemutusan relasi dengan dunia politik penting bagi para hakim agar tidak menjadi alat politik dari satu partai politik. Montesqiueu melihat independency atau peradilan yang bebas dalam hubungan bahwa peradilan merupakan mulut undang-undang sehingga putusan hakim merupakan putusan hukum bukan putusan politik. Karena itu seorang hakim harus tidak memihak dalam proses peradilan dan putus hubungan dengan dunia politik. ${ }^{4}$

Pengadilan sebagai kekuasaan kehakiman harus merdeka dari kekuasaan eksekutif (indepedence from the executive power). Tujuan utama kebebasan dari pengaruh dan kekuasaan eksekutif, mempunyai dua sasaran pokok :

1. untuk menjamin terlaksana peadilan yang jujur dan adil (to ensures a fair and just trial).

2. agar peradilan mampu berperan mengawasi semua tindakan pemerintahan (to enable the judges to exercise control overgovernment action). 5

\section{Tugas dan Kewenangan Kejaksaan}

Yang dimaksud dengan Jaksa adalah pejabat fungsional yang diberi wewenang oleh Undang-Undang untuk bertindak sebagai penuntut umum dan pelaksana putusan pengadilan yang telah memperoleh kekuatan hukum tetap serta wewenang lain berdasarkan undang-undang. ${ }^{6}$

Begitu pula dalam ketentuan pasal 8 ayat (2) UU No. 16 Tahun 2004 menyebutkan "bahwa dalam melaksanakan tugas dan wewenangnya, jaksa bertindak untuk dan atas nama negara serta

\footnotetext{
${ }^{4}$ J. Hendy Tedjonagoro, “Kekuasaan Kehakiman yang Merdeka”, Yuridika Volume 19 No. 4, Juli 2004, hlm. 269.

5 M. Yahya Harahap, Beberapa Tinjauan Mengenai Sistem Peradilan Dan Penyelesaian Sengketa (Bandung: PT. Citra Aditya Bakti, 1996), hlm 5.

${ }^{6}$ Pasal 1 UU. No. 16 Tahun 2004 tentang Kejaksaan RI
} 


\section{Kedudukan Surat Ketetapan Pemberhentian Penuntutan Perkara (SKP3)}

bertanggung jawab menurut saluran hierarki". Jaksa sebagai alat negara mewakili negara, bilamana ada tindakan-tindakan yang telah dilakukan oleh pihak-pihak dan menimbulkan kerugian yang diderita oleh negara dan/atau untuk melindungi kepentingan rakyat.

Dalam menjalankan kekuasaan negara kejaksaan melaksanakannya secara merdeka ${ }^{7}$ artinya jaksa dalam melaksanakan fungsi, tugas, dan wewenangnya terlepas dari pengaruh kekuasaan pemerintah dan pengaruh kekuasaan lainnya. ${ }^{8}$

Sedangkan tugas dan wewenang Jaksa :

(1) Di bidang pidana kejaksaan mempunyai tugas dan wewenang

:

a. Melakukan penuntutan,

b. Melaksanakan penetapan hakim dan putusan pengadilan yang telah memperoleh kekuatan hukum tetap

c. Melakukan pengawasan terhadap pelaksanaan putusan pidana bersyarat, putusan pidana pengawasan, dan keputusan lepas bersyarat

d. Melakukan penyidikan terhadap tindak pidana tertentu berdasarkan undang-undang

e. Melengkapi berkas perkara tertentu dan untuk itu dapat melakukan pemeriksaan tambahan sebelum dilimpahkan ke pengadilan yang dalam pelaksanaannya dikoordinasikan dengan penyidik

(2) Di bidang perdata dan tata usaha negara, kejaksaan dengan kuasa khusus dapat bertindak baik didalam maupun diluar pengadilan untuk dan atas nama negara atau pemerintah.

(3) Dalam bidang ketertiban dan ketentraman umum, kejaksaan turut menyelenggarakan kegiatan :

a. Peningkatan kesadaran hukum masyarakat

b. Pengamanan kebijakan penegak hukum

c. Pengawasan pengedaran barang cetakan

d. Pengawasan aliran kepercayaan yang dapat membahayakan masyarakat dan negara

e. Pencegahan penyalahgunaan dan/atau penodaan agama

7 Pasal 2 UU. No. 16 Tahun 2004 tentang Kejaksaan RI 


\section{Umi Supraptiningsih}

f. Penelitian dan pengembangan hukum serta statistik kriminal. ${ }^{9}$

\section{Penghentian Penuntutan}

Ada 3 kewenangan penuntut umum atas perkara yang tidak dapat dilanjutkan dalam persidangan :

1. Dikeluarkannya SP3 (Surat Pemberhentian Penyidikan Perkara),

2. Penyampingan perkara (deponering), dan

3. SKP3 (Surat Ketetapan Pemberhentian Penuntutan Perkara).

SP3 sudah pernah dikeluarkan oleh penuntut umum ${ }^{10}$, atas terbitnya SP3 tersebut dilakukan gugatan praperadilan oleh TPDI (Tim Pembela Demokrasi Indonesia) dan SPI (Serikat Pengacara Indonesia) dengan alasan proses penyelidikan dan penyidikan oleh Kejaksaan Agung (Kejagung) terhadap kasus KKN (Korupsi Kolusi dan Nepotisme) Pak Harto tidak transparan dan prematur karena dalam penyelidikan dan penyidikan tersebut tidak menjelaskan siapa tersangka dan saksinya. Penyelidikan yang telah menghabiskan waktu hampir satu tahun (Nopember 1998 hingga awal Oktober 1999) namun begitu kasusnya ditingkatkan pada tahap penyidikan dalam waktu yang sangat singkat Kejagung menyimpulkan tidak menemukan bukti-bukti pelanggaran yang dilakukan oleh Pak Harto. Namun apa yang terjadi gugatan praperadilan tersebut ditolak oleh hakim dengan dalih mereka tidak mempunyai kualifikasi sebagai pihak ketiga. ${ }^{11}$ Atas dasar ketentuan pasal 140 ayat (2) KUHAP, yang menegaskan bahwa penuntut umum "dapat menghentikan penuntutan" suatu perkara. ${ }^{12}$ Dasar-dasar penghentian penuntutan tersebut dapat dilakukan oleh penuntut umum, bilamana :

"Dalam hal penuntut umum memutuskan untuk menghentikan penuntutan karena tidak terdapat cukup bukti atau peristiwa tersebut ternyata bukan merupakan tindak pidana atau perkara ditutup demi hukum, penuntut umum

\footnotetext{
9 Pasal 30 UU Tahun 2004 tentang Kejaksaan RI

10 Jawa Pos 20 Oktober 1999

11 Jawa Pos 30 Oktober 1999.

12 M. Yahya Harahap, Pembahasan Permasalahan dan Penerapan KUHAP (Jakarta: Sinar Grafika, 2000), hlm. 436
} 


\section{Kedudukan Surat Ketetapan Pemberhentian Penuntutan Perkara (SKP3)}

menuangkan hal tersebut dalam surat ketetapan, akan tetapi bilamana di kemudian hari ada alasan baru penuntut umum dapat melakukan tuntutan terhadap tersangka".

Artinya Surat Ketetapan Penghentian Penuntutan Perkara yang telah diterbitkan oleh penuntut umum dilakukan pencabutan yang selanjutnya penuntut umum menyerahkan berkas perkara kepada pengadilan untuk dibuka persidangan.

Ada beberapa solusi hukum yang dapat dilakukan oleh penuntut umum selain menggunakan penghentian penuntutan yaitu dengan penyampingan perkara (deponering). Pada penyampingan perkara (deponering), perkara yang bersangkutan memang cukup alasan dan bukti untuk diajukan dan diperiksa dimuka sidang pengadilan. Dari fakta dan bukti yang ada kemungkinan besar terdakwa dapat dijatuhi hukuman, akan tetapi perkara yang cukup fakta dan bukti ini, "sengaja dikesampingkan" dan tidak dilimpahkan ke sidang pengadilan oleh pihak penuntut umum atas alasan : demi untuk kepentingan umum. ${ }^{13}$ Dalam penyampingan perkara hukum dan penegakan hukum dikorbankan demi kepentingan umum. Hal ini akan bersifat diskriminatif dan menyalahi persamaan kedudukan dihadapan hukum (equality before the law).

Sedangkan pada penghentian penuntutan, alasannya bukan didasarkan pada kepentingan umum tetapi semata-mata didasarkan pada alasan dan kepentingan hukum itu sendiri, dengan ketentuan :

1. Perkara yang bersangkutan "tidak" mempunyai pembuktian yang cukup sehingga jika perkaranya diajukan ke pemeriksaan sidang pengadilan diduga keras terdakwa akan dibebaskan oleh hakim atas alasan kesalahan yang didakwakan tidak terbukti. Untuk menghindari keputusan pembebasan yang demikian lebih bijaksana penuntut umum menghentikan penuntutan.

2. Apa yang dituduhkan kepada terdakwa bukan merupakan tindak pidana kejahatan atau pelanggaran. Setelah penuntut umum

13 Yang dimaksud dengan kepentingan umum adalah "kepentingan bangsa dan negara dan/atau kepentingan masyarakat luas". Mengenyampingkan perkara sebagaimana dimaksud dalam ketentuan ini merupakan pelaksanaan asas oportunitas, hanya dapat dilakukan oleh Jaksa Agung setelah memperhatikan saran dan pendapat dari badan-badan kekuasaan negara yang mempunyai hubungan dengan masalah tersebut". 


\section{Umi Supraptiningsih}

mempelajari berkas perkara hasil penyidikan, dan berkesimpulan bahwa apa yang disangkakan penyidik terhadap terdakwa bukan merupakan tindak pidana kejahatan atau pelanggaran, penuntut umum lebih baik menghentikan penuntutan. Sebab bagaimanapun, dakwaan yang bukan merupakan tindak pidana kejahatan atau pelanggaran yang diajukan kepada sidang pengadilan, pada dasarnya hakim akan melepaskan terdakwa dari segala tuntutan hukum (ontstag van rechtvervolging).

3. Alasan ketiga dalam penghentian penuntutan ialah atas dasar perkara ditutup demi hukum atau set aside. Penghentian penuntutan atas dasar perkara ditutup demi hukum ialah tindak pidana yang terdakwanya oleh hukum sendiri telah dibebaskan dari tuntutan atau dakwaan dan perkara itu sendiri oleh hukum harus ditutup atau dihentikan pemeriksaannya pada semua tingkat pemeriksaan. Alasan hukum yang menyebabkan suatu perkara ditutup demi hukum, bisa didasarkan, antara lain :

a. Karena tersangka/terdakwa meninggal dunia.

Dengan meninggalnya tersangka/terdakwa secara otomatis penuntutannya menjadi berhenti karena sesuai dengan asas dalam hukum pidana bahwa suatu perbuatan tindak pidana hanya dapat dipertanggung kepada orang yang melakukan tindak pidana itu sendiri.

b. Atas alasan Nebis in idem

Maksudnya tidak boleh menuntut dan menghukum seseorang dua kali atas pelanggaran tindak pidana yang sama. Sehingga penuntut umum harus menutup pemeriksaan perkara demi hukum (pasal 76 KUHP).

c. Terhadap perkara yang hendak dituntut oleh penuntut umum ternyata telah kedaluwarsa sebagaimana yang telah diatur dalam pasal-pasal 78 sampai dengan pasal 80 KUHP.

Namun demikian penghentian penuntutan tidak dengan sendirinya menurut hukum melenyapkan hak dan wewenang penuntut umum untuk melakukan penuntutan kembali atas perkara tersebut. Penuntut umum akan melakukan penuntutan kembali bilamana :

1. Ternyata dikemudian hari ditemukan "Alasan Baru"

Yang dimaksud dengan alasan baru yaitu sebagaimana yangtelah diatur dalam pasal 140 ayat (2) huruf d KUHAP, yang 


\section{Kedudukan Surat Ketetapan Pemberhentian Penuntutan Perkara (SKP3)}

menjelaskan "bahwa alasan baru tersebut diperoleh penuntut umum dari penyidik yang berasal dari keterangan tersangka, saksi, benda atau petunjuk yang baru kemudian diketahui didapat".

2. Bilamana keputusan praperadilan menetapkan penghentian penuntutan yang dilakukan Penuntut Umum tidak sah menurut hukum.

Dengan adanya penetapan praperadilan yang menentukan penghentian penuntutan tidak sah, dengan sendirinya mewajibkan penuntut umum untuk segera melimpahkan perkara tersebut ke sidang pengadilan.

Berkenaan dengan praperadilan, siapa yang berhak mengajukan gugatan praperadilan :

1. Penyidik,

2. Pihak ketiga yang berkepentingan, yaitu pihak yang telah menderita kerugian (korban).

\section{Terbitnya SKP3 atas Kasus Pak Harto}

Dengan diterbitkannya SKP3 atas kasus Pak Harto, apakah ketetapan ini sudah dianggap tepat atas kasus yang seharus dipertanggung jawabkan oleh orang nomor satu pada masa Orba?

Muncul pro dan kontra atas terbitnya SKP3 tersebut. Sebagian besar masyarakat Indonesia menyatakan bahwa ketetapan ini tidak "adil", bagaimana dengan wibawa hukum kita ? Sistem hukum Indonesia yang menjujung tinggi penegakan hukum.

Berdasarkan hasil Survei Transparency International tahun 2004, Soeharto adalah presiden yang mengorupsi uang negara terbesar senilai 15 miliar - 35 miliyar dollar AS selama 1967 - 1998. Uang yang dikorupsi Suharto jauh di atas Ferdinand Marcos (5 - 10 miliyar dollar AS), Mobutu Sese Seko (5 miliyar dollar AS), atau Slobo dan Milosevic (1 miliyar dollar AS) ${ }^{14}$. Dengan data di atas, yang membuktikan kejahatan ekonomi Pak Harto sebegitu besarnya yang kemudian dengan alasan sakit permanen sehingga dikeluarkannya SKP3, hal ini yang harus ditinjau ulang, tidak adakah solusi hukum lain atas dugaan tindak kejahatan yang dilakukan oleh mantan penguasa Orde Baru tersebut.

\footnotetext{
14 Kompas 15 Mei 2006.
} 


\section{Umi Supraptiningsih}

Dengan terbitnya SKP3 tentunya menyalahi Tap MPR No. XI/MPR/1998 tentang pengusutan dugaan KKN terhadap Soeharto beserta kroni-kroninya yang sampai saat ini masih berlaku (belum dicabut) serta amanat dari Reformasi yang menempatkan pengusutan kasus pak Harto pada rengking teratas.

Pada kajian hukum, melihat kasus Pak Harto dengan mengembalikan pada asas-asas peradilan yang berwibawa. Ada berbagai cara yang dapat ditempuh atas penyelesaian kasus Pak Harto dengan tidak membuat semakin sakitnya masyarakat Indonesia atau setidak-tidaknya dapat meminimalisir perbedaan pandangan antara pro dan kontra atas penyelesain hukum Pak Harto.

1. Proses peradilan atas diri pak Harto harus diteruskan

Dengan tidak mengurangi asas hak asasi manusia karena Pak Harto dalam kondisi sakit dan tidak mungkin dihadirkan dalam persidangan, maka bisa dilakukan persidangan In Absentia (persidangan tanpa hadirnya tersangka) ${ }^{15}$.

Berikanlah kewenangan dan kepercayaan pada hakim untuk melakukan pemeriksaan atas kasus tersebut dengan menjunjung tinggi kekuasaan kehakiman yang merdeka (independence of the judiciary). Dengan tetap memperhatikan asas praduga tidak bersalah (presumtion of inocence)

2. Kewenangan Pemeritah

Begitu proses hukum selesai dengan putusan yang berkekuatan hukum tetap, barulah apa yang menjadi kewenangan Pemerintah untuk memberikan berbagai pertimbangan atas jasa-jasa Pak Harto sebagaimana yang telah diamanatkan oleh UUD 1945 yaitu dengan memberikan amnesti (pengampunan), grasi (keringanan hukuman) ataupun Rehabilitasi (pengembalian nama baik). ${ }^{16}$

Yang menjadi permasalahan berikutnya, bagaimana dengan SKP3 yang sudah terlanjur diterbitkan oleh penuntut umum ? Persoalan yang rumit (lingkaran setan yang tidak kunjung putus). Penuntut umum (kejaksaan) adalah lembaga pemerintahan yang

15 "In Absentia" seharusnya diberikan pengertian yang luas (tidak sempit), sehingga tidak hanya dapat diterapkan pada tersangka yang tidak dapat dihadirkan dalam persidangan dengan alasan tidak diketahui keberadaannya (kabur).

16 Pasal 14 UUD 1945 (hasil amandemen pertama) 


\section{Kedudukan Surat Ketetapan Pemberhentian Penuntutan Perkara (SKP3)}

melaksanakan kekuasaan negara dibidang penuntutan serta kewenangan lain berdasarkan UU17. Dalam melaksanakan kekuasaan negara tersebut harus dilaksanakan secara merdeka ${ }^{18}$. Begitu pula jaksa dalam melaksanakan tugas dan wewenangnya, bertindak untuk dan atas nama negara serta bertanggungjawab menurut saluran hierarki ${ }^{19}$.

Kejaksaan yang telah diberi wewenang sebagai lembaga pemerintahan untuk melakukan penuntutan terhadap "siapapun" yang telah mengakibatkan kerugian terhadap negara. Namun apa yang kemudian terjadi bilamana Kejaksaan itu sendiri yang mengeluarkan SKP3. Siapa selanjutnya yang akan bertindak selaku penuntut untuk mengembalikan kerugian yang telah diderita negara ?

Atas SKP3 tersebut bisa diajukan gugatan praperadilan ${ }^{20}$. Siapa yang berhak untuk mengajukan gugatan praperadilan : 1 . penyidik, dan 2. pihak ketiga.

Dalam kasus SKP3 Pak Harto, Siapa yang lebih tepat mengajukan praperadilan ? apakah pihak ketiga? Selanjutnya timbul pertanyaan lagi Siapa pihak ketiga yang dimaksudkan disini?

Menurut M. Yahya Harahap pihak ketiga adalah pihak yang berkepentingan dalam suatu pemeriksaan perkara pidana. Pada umumnya adalah saksi yang menjadi korban dalam peristiwa pidana yang bersangkutan. Para saksi korbanlah yang paling berkepentingan dalam pemeriksaan tindak pidana. Sedangkan Loebby Luqman berpendapat bahwa yang dimaksud dengan pihak ketiga yaitu pihak yang menjadi korban dalam perkara pidana.

Dari dua pandangan di atas yang dimaksud dengan pihak ketiga yaitu pihak yang menjadi korban dan pihak yang paling berkepentingan (tetapi bukan korban) ${ }^{21}$.

\footnotetext{
17 Lihat Pasal 2 ayat (1) UU No. 16 Tahun 2004 tentang Kejaksaan RI.

18 Secara merdeka adalah Jaksa dalam melaksanakan fungsi, tugas dan wewenangnya terlepas dari pengaruh kekuasaan pemerintah dan pengarus kekuasaan lainnya.

${ }^{19}$ Lihat Pasal 8 ayat (2) UU No. 16 Tahun 2004 tentang Kejaksaan RI.

20 Praperadilan $($ pra $=$ sebelum, peradilan $=$ mengadili $)$

21 Didik Endro Purwoleksono, "Siapa yang Dimaksud dengan Pihak Ketiga dalam Praperadilan Kasus Mantan Prediden Soeharto", Puspa Ragam Informasi dan Problematika Hukum, Unit Informasi dan Studi Hukum - Fakultas Hukum Universitas Airlangga, Oktober 2000, hlm. 58.
} 


\section{Umi Supraptiningsih}

Karena pihak yang menjadi korban dalam kasus SKP3 Pak Harto adalah Negara yang dalam kewenangannya menjadi tanggung jawab Kejaksaan dan kejaksaan itu sendiri yang telah mengeluarkan SKP3 sehingga tidak mungkin kalau gugatan praperadilan itu diajukan oleh Kejaksaan. Sehingga dalam kasus SKP3 tersebut yang tepat untuk mengajukan gugatan praperadilan adalah pihak yang paling berkepentingan (tetapi bukan korban), dalam hal ini bisa dilakukan oleh masyarakat dan/atau lembaga yang konsen atas penegakan keadilan di Indonesia, misalkan TPDI (Tim Pembela Demokrasi Indonesia), PBHI (Perhimpunan Badan Hukum Indonesia) dan lain-lain.

Dikabulkan tidaknya gugatan praperadilan menjadi wewenang hakim untuk meriksa, memutus dan menyelesaikannya. Diharapkan hakim tidak saja sebagai corong UU tetapi juga memperhatikan azas keadilan dan kemanfaatan. Dan hakim dituntut dapat menggali dan menciptakan hukum (rechtvinding).

Segala apa yang dilakukan dan diputuskan oleh hakim tidak hanya dipertanggung jawabkan kepada masyarakat tetapi juga harus dipertanggung jawabkan dihadapan Tuhan Yang Maha Esa, oleh sebab itu segala putusan hakim harus berkepala "Demi Keadilan Berdasarkan Ketuhanan Yang Maha Esa" .22

\section{Penutup}

Untuk terciptanya penegakan hukum dan menjamin wibawa hukum di Indonesia diharapkan dalam mengambil keputusan berupa penetapan sebagaimana yang telah dikeluarkan oleh Kejaksaan yaitu berupa Surat Ketetapan Pemberhentian Penuntutan Perkara (SKP3) harus mendasarkan demi kepentingan bangsa dan negara serta ketertiban umum. Diharapkan dalam memahami hukum, hukum harus diberi pengertian yang luas, itulah fungsinya legal Opinion. Dengan mendasarkan pada ketentuan tersebut, maka kedudukan SKP3 tersebut dapat dilakukan upaya gugatan praperadilan yang dilakukan oleh Pihak Ketiga (yang bukan korban). Dengan Praperadilan tersebut kita serahkan kepada hakim untuk menguji sah tidaknya SKP3 tersebut.

${ }^{22}$ Lihat pasal 4 ayat (1) UU No. 4 Tahun 2004. 